\title{
Water Quality Characteristics of Jonge Telaga (Doline Pond) as Water Resources for the People of Semanu District Gunungkidul Regency
}

\section{Widyastuti and Eko Haryono}

Received: 0312 2015 / Accepted: 1205 2016 / Published online: 30122016

(๑) 2016 Faculty of Geography UGM and The Indonesian Geographers Association

\begin{abstract}
Doline ponds (telaga) have an important role as one of water resources in karst areas, especially during dry seasons in Gunungkidul. Recently, the doline ponds are facing various environmental problems, i.e. steadily decreasing water storage, water loss, and degrading water quality. The research aims to determine the characteristics of Jonge Telaga which include the continuity of flow, utilization, pollution sources, physical water quality (temperature, EC,TDS, TSS, and turbidity), chemical water quality $\left(\mathrm{pH}, \mathrm{NO}_{2}, \mathrm{NO}_{3}, \mathrm{NH}_{4}, \mathrm{PO}_{4}, \mathrm{BOD}, \mathrm{COD}\right.$, and detergent), and biological water quality (total coliform). In order to determine the characteristics of Jonge Telaga, the research was conducted using a survey method, i.e., observing the continuity of flow and measuring physical, chemical, and biological water quality. Initially, the water was sampled purposively based on the area and the depth of this doline pond. The qualitative description of the results shows that Jonge Telaga is a closed perennial doline pond, whose main pollution source comes from domestic activities, such as bathing and washing. According to the Governor Regulation of the Special Region of Yogyakarta Number 20 Year 2008 on Water Quality Standards, Jonge Telaga meets all of the water quality criteria, except the temperature and detergent, for a Class II water.
\end{abstract}

Keywords: doline pond, doline, karst, water quality, water consumption, water resources, water storage

\begin{abstract}
Abstrak Telaga mempunyai peran penting sebagai salah satu sumberdaya air di daerah karst, khususnya pada musim kemarau di Kabupaten Gunungkidul. Pada saat ini telaga menghadapi berbagai permasalahan lingkungan yaitu simpanan air yang terus berkurang, air yang cepat hilang, dan penurunan kualitas air. Tujuan penelitian adalah untuk mengetahui karakteristik telaga yang meliputi kontiyuitas aliran, pemanfaatan, sumber pencemar, kualitas fisik air telaga (TDS, TSS, suhu, kekeruhan, DHL), kimia air ( $\mathrm{pH}, \mathrm{NH}_{4}, \mathrm{PO}_{4}, \mathrm{NO}_{2}, \mathrm{NO}_{3}, \mathrm{BOD}, \mathrm{COD}$, deterjen) dan biologi air (coliform total). Penelitian ini dilaksanakan berdasarkan metode survei. Untuk mengetahui karakteristik telaga dilakukan pengamatan kontinyuitas aliran, pengukuran kualitas air secara fisik, kimia dan biologi. Pengambilan sampel air dilakukan secara purposive mendasarkan pada luasan dan kedalaman telaga. Analisis hasil dilakukan secara deskriptif kualitatif. Hasil penelitian menunjukkan bahwa Telaga Jonge merupakan telaga yang tertutup dengan ketersediaan air menerus sepanjang tahun. Sumber pencemar utama telaga adalah kegiatan domestik (mandi dan cuci). Kualitas air Telaga Jonge menurut baku mutu air kelas II PERGUB DIY Nomor 20 Tahun 2008 masih di bawah ambang batas kecuali suhu dan deterjen.
\end{abstract}

Kata kunci : telaga dolin, karst, kualitas air, konsumsi air, sumberdaya air, simpanan air

\section{Introduction}

Karst area is a landscape characterized by a unique hydrology. It makes karst a complex aquifer due to secondary porosity development, forming a more developed subsurface drainage and, hence, a rare surface drainage [Ford and Williams, 2007]. Because of the deeply located groundwater (underground river), water resources in karst areas

${ }^{1} \mathrm{M}$. Widyastuti and ${ }^{2}$ Eko Haryono Department of Environmental Geography, Faculty of Geography, Universitas Gadjah Mada

E-mail: ${ }^{1}$ m.widyastuti@geo.ugm.ac.id; ${ }^{2}$ e.haryono@ugm.ac.id are hardly accessible.

Doline is a karstic landform, of which the shape is a closed round or oval depression with a size of several meters to about one kilometer [Ford and Williams, 2007]. Sweeting [1972] categorized doline as a medium-sized landform. According to karst literature, it is often referred to by various terms: sinkhole, sink, swallow hole, cenote, and blue hole [Haryono and Adji, 2004]. Every doline or closed depression is composed of three components [White, 1988], namely a drain, which is a channel with high permeability that drains water from doline into the underground system, a 
Indonesian Journal of Geography, Vol 48, No. 2, December 2016: 157 - 167

solutionally altered zone below the bedrock surface, and a soil cover, colluvium, glacial deposit, volcanic ash or other loose material. However, surface material is not evenly distributed in every part of doline. A temporarily or perennially rainwaterfilled doline is termed telaga (doline pond). Aside from the influence of external factors such as evapotranspiration, the capacity or volume of a doline pond is controlled by its characteristics.

Because of the concomitant drought events or water issues of a karst area, water resource becomes a pressing issue in Gunung Sewu karst area. Most of the local people have no access to clean water. Therefore, doline ponds used to support $90 \%$ of water supply in the area especially before the 1990s when water supply infrastructure had not been constructed [Haryono et al., 2009]. Nowadays, many doline ponds turned dry. Only $30 \%$ of all doline ponds in Gunung Sewu remain providing water throughout the year. In some parts of the area, local people are forced to fetch water from springs or doline ponds because the groundwater (underground river) is found at a depth of more than 100 masl and, therefore, difficult to access.

Gunungkidul, one of the regencies of the Special Region of Yogyakarta, is notorious for its water scarcity during dry seasons, especially in the karst area. In addition to groundwater (underground river) and spring, water resource used to fulfill the needs of the local people is doline pond. According to Haryono et al. [2009], there are 443 doline ponds scattered throughout Gunung Sewu karst area, 282 of which are located in several districts in Gunungkidul. The districts are Purwosari, Panggang, Saptosari, Playen, Paliyan, Tanjungsari, Tepus, Girisubo, Rongkop, Semanu, and Ponjong.

Various existing problems in doline ponds include decreasing water storage, water loss, and degrading water quality. Aside from natural factors, the behavior of people around them also takes part in the emergence of these problems. In this case, the role of institutions becomes an integral part of doline pond management. The water storage of doline ponds decreases due to rapid sedimentation and infiltration rate. In addition, it may disappear due to bed sediment leak, caused by soil cover removal during lake deepening and construction building around them, and high evaporation rate. Meanwhile, water quality degradation is caused by a variety of activities within the doline ponds, such as bathing (humans and domestic animals) and washing, which introduce pollutants into the water. In addition, the surrounding land use may affect the water quality, particularly in relation to both organic and inorganic fertilizers.

An input of continuous pollution load may exceed the natural capacities of doline ponds to accommodate pollution loads that lead to water quality degradation. Even though doline ponds are hydrologically different from lakes or reservoirs, which have a real water circulation due to the presence of inlet and outlet, the assessment of their pollution load capacities uses the slightly modified principles of the same assessment for lakes or reservoirs. Therefore, the study of pollution load capacity is necessary to sustain the function of doline ponds quantitatively and qualitatively for their users, the local people.

The research is located in Wonosari Basin, Semanu District, Gunungkidul Regency. As a distinctive landform and morphology, the potential of doline ponds to support water resources in Gunungkidul, particularly during dry seasons, needs to be addressed. The existing doline ponds have been experiencing problems related to decreasing water quantity and degrading water quality. Therefore, this research aims to determine the characteristics of Jonge Telaga which include the continuity of flow, utilization, pollution sources, physical water quality, chemical water quality $\left(\mathrm{pH}, \mathrm{NH}_{4}, \mathrm{PO}_{4}, \mathrm{NO}_{2}, \mathrm{NO}_{3}, \mathrm{BOD}, \mathrm{COD}\right.$, detergent), and biological water quality (total coliform).

\section{The Methods}

This research used various thematic maps, namely 1: 25,000 topographic maps (Rupa Bumi Indonesia) and 1: 30,000 aerial photos, supporting data from the results of previous related research, and the water samples of Jonge Telaga. In addition, it used a set of hydrological data consisting of physical, chemical, and biological (total coliform) water quality as well as the condition of Jonge Telaga and its pollution source. All data, variables, and parameters were determined in accordance with the method used in this research.

The research was conducted using a survey method with emphases on observation and variable measurement. Data collection technic was based on water sampling, whose locations were 
determined using a purposive sampling method, viz. a sampling technic based on a consideration that the properties of the samples are already known and in accordance with the observed issues and research objectives. Jonge Telaga was determined as a research object due to its perennial continuity of flow. In order to determine its physical, chemical, and biological water quality, the research used several water samplings whose locations represent the strata, depth, and width of this doline pond.

The equipment used during variable measurement in Jonge Telaga included a geodetic GPS, a set of sampling equipment (bottles for water samples and icebox), and a camera. Meanwhile, data process and analysis used a set of hardware (CPU, computer, printer, and monitor) and a mapping software, ArcView.

Research data were acquired through direct field measurement (primary data) and institutional survey (secondary data). The primary data consisted of the condition, the utilization, and the physical, chemical, and biological water quality of Jonge Telaga. Field measurement included physical properties of water, such as temperature and Electrical Conductivity (EC), and chemical properties, such as $\mathrm{pH}$. Meanwhile, laboratory analysis included: 1) physical properties: TSS, TDS, and turbidity; 2) chemical properties: $\mathrm{NH}_{4}, \mathrm{PO}_{4}$, $\mathrm{NO}_{2}, \mathrm{NO}_{3}, \mathrm{BOD}, \mathrm{COD}$, and detergent; and 3) biological properties: total coliform. Afterward, the analysis results of all water properties were compared to the Class II water quality criteria, as determined by the Governor Regulation of the
Special Region of Yogyakarta Number 20 Year 2008, considering the utilization of Jonge Telaga for touristic purposes. Its condition, utilization, and pollution source were obtained from unstructured interviews to the people around it. Meanwhile, the secondary data consisted of supporting data for analysis, such as rainfall, geology and geomorphology, soil, land use, and population.

In order to obtain the spatial context of the characteristics of Jonge Telaga, the research used tables, figures, and maps. And, in order to explain the relationship between variables, the results were described qualitatively.

\section{Result and Discussion}

Jonge Telaga is located in Jonge Hamlet, Pacarejo Village, Semanu District, Gunungkidul Regeny. It lies on an area of $31,310.69 \mathrm{~m}^{2}$ with a perimeter of $780.28 \mathrm{~m}$ and a volume of $46,690.32$ $\mathrm{m}^{3}$. Geographically, it is located between 9114384 $9114600 \mathrm{mU}$ and $458587-458863 \mathrm{mT}$. The location of the doline pond is mapped in Fig. 1.

The area rainfall of every district in Gunungkidul varies between 1,275-2,454 mm/year, while the temperature varies between $24.9-26.6^{\circ} \mathrm{C}$ [Sudarmadji et al, 2010]. Administratively, the research area is part of Semanu District that has a rainfall depth of more than 2,000 $\mathrm{mm}$ /year, an average monthly temperature of $24.4-26.0^{\circ} \mathrm{C}$, and a potential evapotranspiration of 129.6-143.6 $\mathrm{mm} / \mathrm{month}$ [Sudarmadji et al., 2006]. Rainfall is the main water input in Jonge Telaga, which also means that it is the main supply for the water storage of Jonge Telaga. Meanwhile, the main water

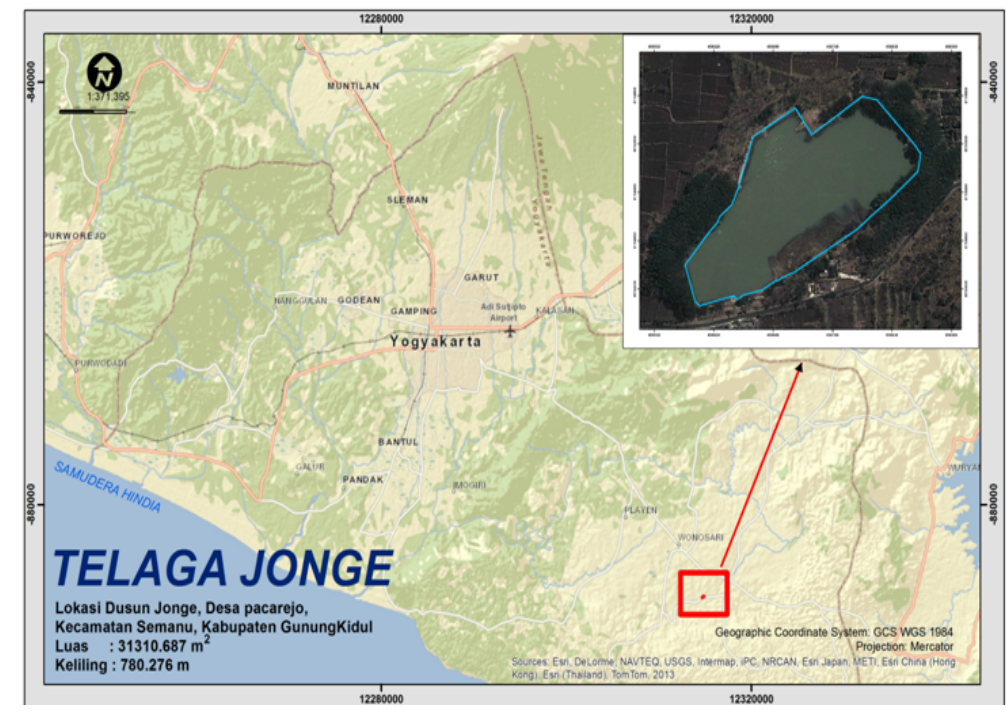

Figure 1. The Location of Jonge Telaga in Pacarejo Village, Semanu District, Gunungkidul 
Indonesian Journal of Geography, Vol 48, No. 2, December 2016: 157 - 167

loss is due to evapotranspiration. Water circulation almost never occurs in Jonge Telaga because this doline pond is a closed depression. An artificial inlet was constructed to accommodate runoff coming from the surrounding area. Meanwhile, the outlet is a spillway funneling surplus water from the doline pond. Jonge Telaga is a perennial doline pond, which means that it is never dry even when the water level declines in dry seasons.

Based on the 1: 100,000 Geologic Maps, the research area is part of Wonosari Formation. It is entirely composed of limestones, viz., wellbedded limestone and massive reef limestone that form a karst topography, and marly limestone and conglomeratic limestone. Furthermore, tuffaceous sandstone and silt are found in this formation [Surono et al., 1992]. Wonosari Fm is a Mid Miocene-Pliocene formation whose bedrock is composed of Oligocene-Miocene volcanic rock and clastic volcanic rock (Semilir, Sambipitu, Jaten, Wuni, Nampol Formation). It interfingers with the underneath Oyo Fm and with the above Kepek Fm. It composes the entire Wonosari Basin and Gunung Sewu with a thickness of 300-800 m.

The research area is physiographically located in Wonosari Basin. According to Pannekoek [1949], it is part of the southern zone of Java Island, genetically part of the southern plateau in Java Island, formed as a peneplain that was uplifted and folded in the Mid Pleistocene Epoch $( \pm$ 1-1.8 million years ago); hence, the existence of wide depressions. The bedrock of the peneplain is composed of Wonosari Fm limestones. Wonosari Basin is surrounded by Baturagung Range (a range of structural hills) in the north and the west, Panggung Masif in the east, and the complex of Gunung Sewu karst in the south and the west. It is also referred as a lagoonal limestone-composed basin. This unit is a depression with flat (slope 0$3 \%$ ) to undulating (slope 3-8\%) topography and sparsely to densely distributed rills of less intensive erosion. Depositional process of the debris from its surrounding hillslopes, offset by surface and linear erosion, leads to a relatively thin soil layer.

According to the Center for Soil Research in Bogor, the commonly developed soil in Wonosari Basin is Typic Hapluderts. The soil is formed by clay deposit or colluvium (parent materials) in a closed basin with flat to undulating topography and a slope of $0-8 \%$. The average annual temperature is $25^{\circ} \mathrm{C}$, while the rainfall is
$1,800 \mathrm{~mm}$; hence, the udic moisture regime. The soil is utilized as dryland agriculture with several main crops, namely paddy, soy, corn, tobacco, and hummingbird tree (Sesbania grandiflora). It has a depth of more than $90 \mathrm{~cm}$, a somewhat poor drainage, and a low permeability. During dry seasons, it cracks with a width of more than $5 \mathrm{~cm}$. It is also characterized by dark reddish brown color (5YR 3/2), subangular blocky structure, sticky (wet) consistency and firm (dry) consistency, and slickenside.

Jonge Telaga is located in Pacarejo Village. According to the Statistics Indonesia (2012), the land use in Pacarejo is dominated by dryland $(1,599.30$ ha; $52.02 \%)$. Other land uses are paddy field (2.2 ha; $0.07 \%)$, settlement (546.67 ha; $17.78 \%$ ), community forest ( $59.30 \mathrm{ha}$; $1.93 \%$ ), state forest (399.31 ha; $12.99 \%)$, and other land use (467.53 ha; $15.21 \%$ ). The surrounding area of Jonge Telaga is utilized as dryland agricultural practice (north, east, and west side), settlement (south), and rainfed paddy field (north and west side).

The total population of Pacarejo is 15,969 ; 7,968 of which are male and 8,001 of which are female [BPS, 2012]. It is $28.58 \%$ of the total population of Semanu District. The area of Pacarejo is $3,074.31$ ha and, therefore, the population density is 5 people/ha. Based on the productive age group, most of the population in Pacarejo is adult (76\%), while the rest of the population is at the age of child (24\%).

\section{The Characteristics of Jonge Telaga}

Jonge Telaga is a perennial doline pond, i.e., never dry even during dry seasons, whose water supply is mainly from rainfall and water loss is likely due to evaporation. The inlet is limited to channel water from the surrounding area - i.e., no inflow from a particular river. Meanwhile, the outlet is functional only when it exceeds its maximum storage capacity.

The banks of Jonge Telaga are cemented and equipped with six inlets and one outlet (a spillway). Along these banks, a walking trail accommodates the visitors to enjoy the view of doline pond and the comforting shade trees growing around it. However, the walking trail is still undergoing a construction. In order to maintain its function as a tourist attraction, fish seeds are stocked into the doline pond, raised, and then harvested twice a year through a fishing 
competition. The competition is managed by the local youth organization (karang taruna).

Nowadays, Jonge Telaga is the main water resource for the people of the surrounding five hamlets. They mostly do washing and bathing close to the shore. Therefore, during certain hours in the mornings and in the afternoons, the doline pond is crowded with the local people. On the other hand, people outside these five hamlets utilize it as a natural tourist destination due to its preserved nature and beauty.

\section{Pollutant Source}

Bathing and washing directly in the doline pond become the main pollutant sources of Jonge Telaga. These kinds of activities may lead to an accumulation of phosphate and detergent at the bottom of the doline pond and increase the probability of eutrophication. In addition to liquid waste, solid waste is still found along the shore, such as plastic wraps, beverage bottles, or cardboard boxes, even though there are already trashcans and no-trashing signs. The agricultural practices around it also have a potential to contribute as pollutant sources. The rainfallinduced surface runoff transfers the residue of organic and inorganic fertilizers through the inlet of Jonge Telaga.

\section{Water Quality}

The water quality of Jonge Telaga is determined by 10 water samplings. Their distribution is presented in Figure. 2.

\section{Physical Water Quality}

The analyzed physical parameters include water temperature, Electrical Conductivity (EC), Total Suspended Solids (TSS), Total Dissolved Solids (TDS), and turbidity.

\section{Water Temperature and Electrical Conductivity} (EC)

Direct measurement in Jonge Telaga shows that the temperature varies from 29.1$30.7^{\circ} \mathrm{C}$, as seen in Table 1 . According to the Class II water quality standard issued in the Governor
Regulation of the Special Region of Yogyakarta Number 20 Year 2008 (BLH, 2008), it is above the natural temperature. It is caused by various factors including a direct measurement during the daytime and a closed doline pond - i.e., no water circulation (no water input nor output). The sunlight that enters the water body is transformed into heat energy. It occurs most effectively at the top layer and, therefore, makes this layer warmer and less dense than the lower layer [Effendi, 2003].

Table 1. The Temperature and Electrical Conductivity (EC) in Jonge Telaga

\begin{tabular}{ccc}
\hline Samples & $\begin{array}{c}\text { Temperature } \\
\left({ }^{\circ} \mathrm{C}\right)\end{array}$ & $\begin{array}{c}\text { EC } \\
(\mu \mathrm{mhos} / \mathrm{cm})\end{array}$ \\
\hline A1 & 29.4 & 115 \\
A2 & 29.2 & 116 \\
B1 & 29.6 & 117 \\
B2 & 29.7 & 114 \\
C1 & 29.3 & 118 \\
C2 & 29.9 & 110 \\
D1 & 29.1 & 116 \\
D2 & 29.5 & 115 \\
D3 & 30.4 & 112 \\
D4 & 30.7 & 115 \\
Average & 29.68 & 114.8 \\
\hline
\end{tabular}

Source: Direct Measurement, 2013

Electrical Conductivity (EC) represents the ability of water to flows electricity. The more dissolved salts to ionize, the higher the EC. Table 1 shows that the EC of the research area is between $110-117 \mu \mathrm{mhos} / \mathrm{cm}$, which means there is no wide variation in values. EC is not part of the Class II water quality criteria issued by the Governor Regulation of the Special Region of Yogyakarta Number 20 Year 2008. However, the EC of Jonge Telaga is generally the same as that of other surface water bodies.

Telaga varies between $16-616 \mathrm{mg} / \mathrm{L}$, which is below the threshold. The lowest concentration is found in A1, while the highest one is found in $\mathrm{C} 2$ (Figure 3). 


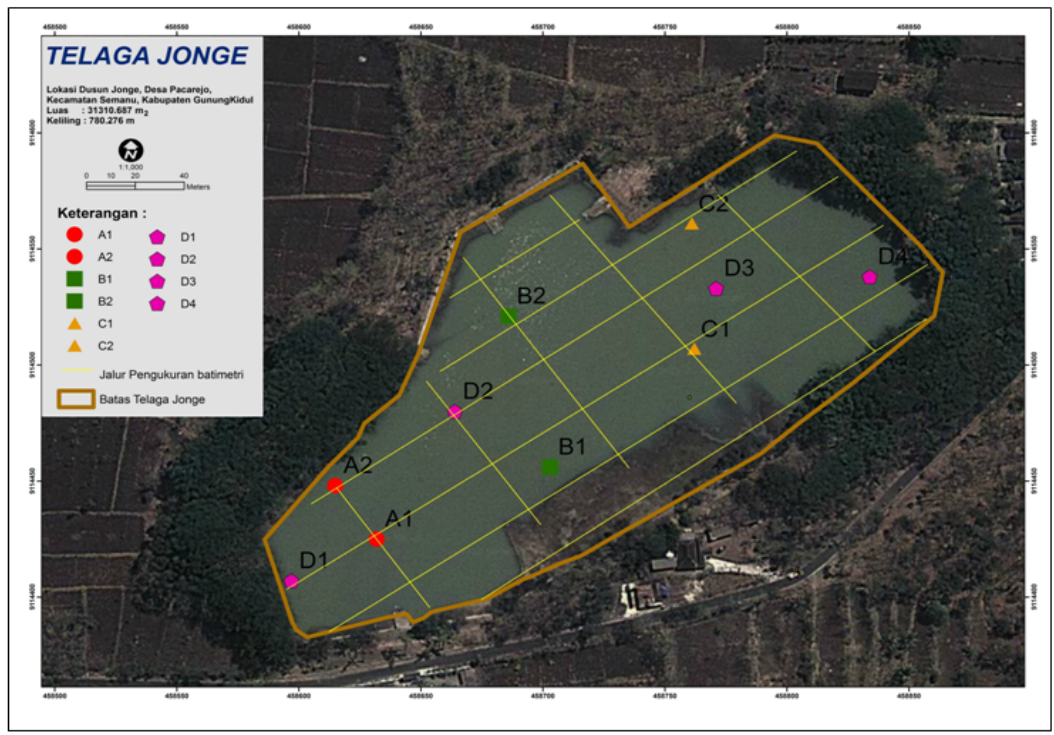

Figure 2. The Locations of Water Samplings in Jonge Telaga (Widyastuti, et.al, 2014)

\section{Total Suspended Solids (TSS)}

TSS (diameter $>1 \mathrm{~mm}$ ) is particles retained by 0.45 -micron filters (Effendi, 2003). It consists of silt and fine sand as well as microorganism, which are resulted especially by soil erosion on the surrounding area. TSS has a positive relationship with the turbidity level of a water body. The higher the TSS, the higher the turbidity. The TSS of Jonge Telaga varies between 9.5-75.4 mg/L. Based on the Governor Regulation of the Special Region of Yogyakarta Number 20 Year 2008, the threshold of TSS for a Class II water is $50 \mathrm{mg} / \mathrm{L}$. Accordingly, some of the water samples (Fig. 3) exceed the threshold (red line), namely A2, B2, C1, C2, D3, and D4. The highest concentration of TSS is found in C1.

\section{Total Dissolved Solids (TDS)}

TDS is dissolved particles (diameter $<10^{-6} \mathrm{~mm}$ ) and colloid (diameter between $10^{-6}-10^{-3} \mathrm{~mm}$ ) in the forms of chemical compounds and other materials that are not retained by 0.45 -micron filters [Rao, 1992 in Effendi, 2003]. Based on the Governor Regulation of the Special Region of Yogyakarta Number 20 Year 2008, the threshold of TDS for a Class II water is $1,000 \mathrm{mg} / \mathrm{L}$. The TDS of Jonge

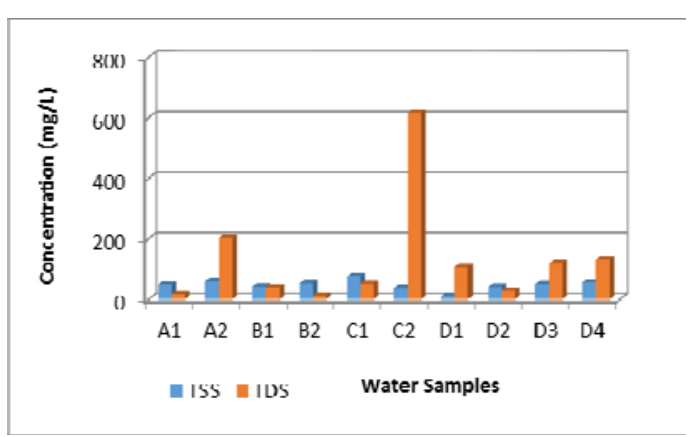

Figure 3. The TSS and TDS Concentration of the Water Samples of Jonge Telaga

\section{Turbidity}

Turbidity describes the optical nature of a water body. It is based on the amount of the light absorbed and emitted by particles in the water body [Effendi, 2003]. A turbidity is caused by the presence of organic and inorganic particles suspended and dissolved in the water, in the form of either planktons or other microorganisms [Davis and Cornwell, 1991 in Effendi, 2003]. The level of turbidity is expressed in Nephelometric Turbidity Units (NTU). It has a positive relationship with the concentration of TSS, i.e., the higher the turbidity, the higher the TSS. However, a higher turbidity is not always followed by a higher concentration of TDS. Laboratory analysis shows that the turbidity of Jonge Telaga varies between 29.03-437 NTU. The lowest turbidity is found in water sample B1, 
while the highest one is found in $\mathrm{C} 1$, as presented in Fig. 4. Turbidity is not part of the Class II water quality criteria issued by the Governor Regulation of the Special Region of Yogyakarta Number 20 Year 2008. However, this level of turbidity allows Jonge Telaga to preserve its beauty and function as a tourism object.

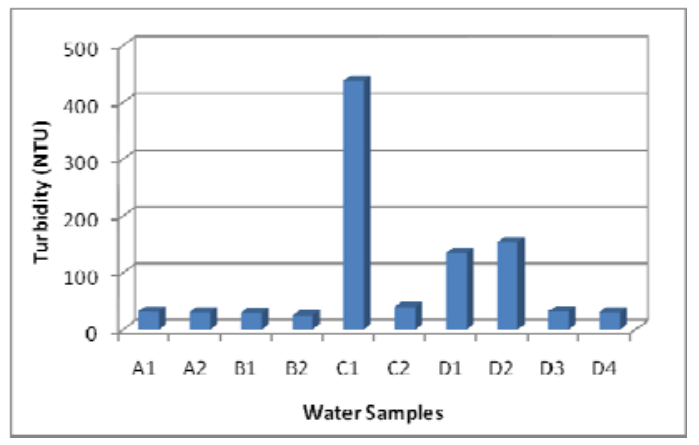

Figure 4. The Turbidity Level of the Water Samples of Jonge Telaga

\section{Chemical Water Quality}

The analyzed chemical parameters include $\mathrm{pH}$, nitrate $\left(\mathrm{NO}_{3}{ }^{-}\right)$, nitrite $\left(\mathrm{NO}_{2}^{-}\right)$, ammoniac $\left(\mathrm{NH}_{3}{ }^{-}\right.$ $\mathrm{N})$, phosphate $\left(\mathrm{PO}_{4}^{-} \mathrm{P}\right)$, Biochemical Oxygen Demand (BOD), Chemical Oxygen Demand (COD), and detergent (Methyne Blue Active Substance - MBAS).

\section{Acidity Level (pH)}

Acidity level $(\mathrm{pH})$ has a significant role in both biological and chemical processes in a water body. Tebutt [1992] and Fetter [1999] stated that $\mathrm{pH}$ represents the concentration of hydrogen ions, while Mackereth et al. (1989, in Effendi 2003) described $\mathrm{pH}$ to have a strong relationship with alkalinity and carbon dioxide. A low $\mathrm{pH}(<5)$ may indicate a zero alkalinity level - i.e., the higher the $\mathrm{pH}$, the higher the alkalinity. Meanwhile, the opposite is true for carbon dioxide - i.e., the higher the $\mathrm{pH}$, the lower the free carbon dioxide. An acidic solution (low $\mathrm{pH}$ ) is corrosive. $\mathrm{pH}$ also controls the toxicity of a chemical compound. Direct measurement shows that the $\mathrm{pH}$ of Jonge Telaga varies between 7.49-7.83. All of the samples are above seven with no wide variation. Based on the Governor Regulation of the Special Region of Yogyakarta Number 20 Year 2008, the pH of a Class II water is between 6 and 8.5. Therefore, the $\mathrm{pH}$ of Jonge Telaga is within the accepted limit for a Class II water.
Nitrate $\left(\mathrm{NO}_{3}{ }^{-}\right)$

Nitrate is the main form of nitrogen in natural waters. It is highly water-soluble and stable. It is the result of a perfectly oxidized nitrogen during nitrification. Nitrate is present in a very small amount in surface water $(<0.1 \mathrm{mg} / \mathrm{L})$, while a much larger amount in groundwater $(100 \mathrm{mg} / \mathrm{L})$. A presence of more than $5 \mathrm{mg} / \mathrm{L}$ in surface water indicates a human-induced pollution, e.g., from domestic activities, fertilizers, industrial waste, plant decomposition, and animal waste. Meanwhile, a presence of more than $50 \mathrm{mg} / \mathrm{L}$ is deemed harmful for health [Davis and Cornwell, 1991 in Effendi, 2003]. According to the Governor Regulation of the Special Region of Yogyakarta Number 20 Year 2008, nitrate in a Class II water is $10 \mathrm{mg} / \mathrm{L}$. Laboratory analysis shows that nitrate in Jonge Telaga varies between 0.26-1.14 mg/L (Figure 5), which is below the accepted threshold. Therefore, no nitrate-contained pollutant in the doline pond.

\section{Nitrite $\left(\mathrm{NO}_{3}^{-}\right)$}

Nitrite is present in a very small amount in natural waters, $0.001 \mathrm{mg} / \mathrm{L}$, because it is not stable and easily oxidized into nitrate (Effendi, 2003). It is an intermediate product of nitrification and denitrification. It is a toxic compound originated from industrial and domestic waste. Laboratory analysis shows that nitrite in all of water samples of Jonge Telaga varies between 0.32-12.68 mg/L (Figure. 5). The lowest nitrite is present in sample $\mathrm{C} 2$, while the highest one is in A2. Nitrite is not part of water quality parameter issued by the Governor Regulation of the Special Region of Yogyakarta Number 20 Year 2008. However, based on the Government Regulation Number 82 Year 2001, nitrite in a Class II water is $0.06 \mathrm{mg} / \mathrm{L}$. As a conclusion, nitrite in every water sample exceeds the accepted threshold and possesses a threat to human's health. 


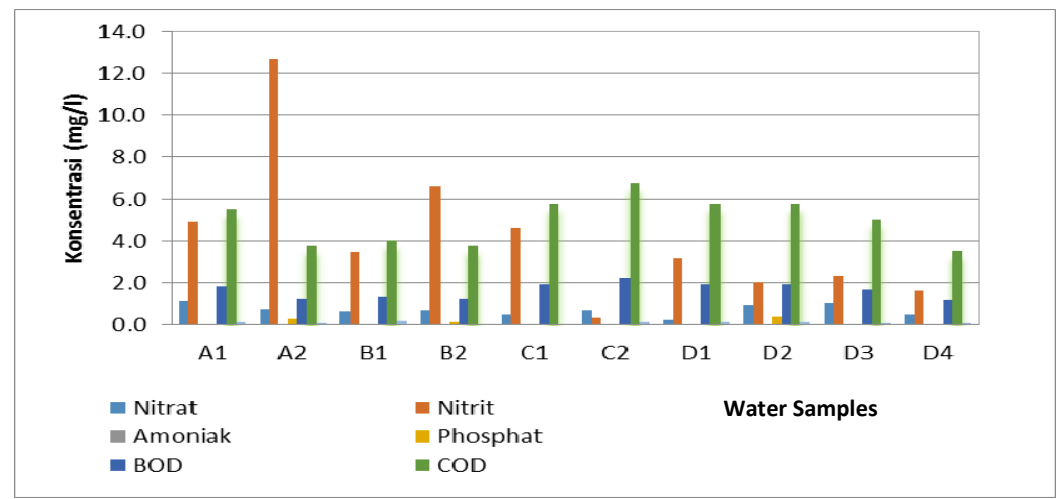

Figure 5. The level of Nitrate, Nitrite, Ammoniac, Phosphate, BOD, COD, and Detergent in Every Water Sample of Jonge Telaga

\section{Ammoniac $\left(\mathrm{NH}_{3}{ }^{+} \mathrm{N}\right)$}

Ammonium is part of inorganic nitrogen, which is one of the nitrogen source able to be absorbed by plants. The measured ammonia in waters is total ammonia $\left(\mathrm{NH}_{3}{ }^{+}\right.$and $\left.\mathrm{NH}_{4}^{+}\right)$. Free ammonia is not ionizable, while ammonia is the opposite. Ammonium is the product of change in nitrogen compound (ammonia) at a low-pH environment [Alarets and Santika, 1984]. Its anthropogenic source is wastewater (urine) or organic matter decomposition; hence, its pollutant nature. Analysis shows that ammoniac in Jonge Telaga varies between $0.0309-0.0503 \mathrm{mg} / \mathrm{L}$ with the lowest presence found in sample D2 and the highest one in sample A2 (Figure 5). According to the Governor Regulation of the Special Region of Yogyakarta Number 20 Year 2008, ammoniac is not part of a Class II water quality parameter. However, according to Sawyer and McCarry [1978], the presence of ammoniac in waters should not exceed $0.2 \mathrm{mg} / \mathrm{L}$ due to its toxic nature for aquatic organisms.

\section{Phosphate $\left(\mathrm{PO}_{4}{ }^{3-}\right)$}

Phosphorus is not present as a free element in waters but rather as a dissolved inorganic compound (orthophosphate and polyphosphate) and particulate organic compound. Phosphate in the form of phosphorus is absorbable by plants [Dugan, 1972 in Effendi, 2003]. In a water body, phosphorus changes continuously because of decomposition and organic and inorganic synthesis by microbes. Naturally, phosphate is present in a relatively small amount because its source is also less than other elements, such as nitrogen. Its natural concentration is around $0.005-0.02 \mathrm{mg} / \mathrm{L}$ in surface water and around $0.02 \mathrm{mg} / \mathrm{L}$ in groundwater [Effendi, 2003]. In addition, phosphorus is also resulted from organic matter decomposition and anthropogenic-induced waste, such as industrial and domestic waste (detergent) and the residual fertilizer from agricultural practices.

Laboratory analysis shows that Jonge Telaga contains a relatively small phosphate. Eight of ten water samples contain less than $0.02 \mathrm{mg} / \mathrm{L}$ (limit of detection of the analysis equipment), and one of which contains $0.15 \mathrm{mg} / \mathrm{L}$ (sample B2). The other two water samples, A2 and D3, exceed the accepted threshold for a Class II water (the Governor Regulation of the Special Region of Yogyakarta Number 20 Year 2008), which is 0.2 $\mathrm{mg} / \mathrm{L}$ (Fig. 5). The main source of phosphate in Jonge Telaga is washing directly in the doline pond.

\section{Biochemical Oxygen Demand (BOD)}

Biochemical Oxygen Demand (BOD) is the amount of oxygen required by aerobic microbes to oxidize organic matter into carbon dioxide and water [Alaert and Santika, 1984]. In other words, BOD represents the amount of oxygen consumed by aerobic microbial respiration occurring in $\mathrm{BOD}$ bottles that are incubated at $20^{\circ} \mathrm{C}$ for five days without light [Boyd, 1998 in Effendi, 2003]. An increase in BOD is an indicator of pollution. Laboratory analysis shows that BOD in Jonge Telaga varies between 1.17-1.92 mg/L. The lowest BOD is present in sample D4, while the highest one is in sample C1, D1, and D2 (Fig. 5). Based on the Governor Regulation of the Special Region of Yogyakarta Number 20 Year 2008, the threshold for 
BOD in a Class II water is $3 \mathrm{mg} / \mathrm{L}$. Therefore, BOD in Jonge Telaga is below the accepted threshold.

\section{Chemical Oxygen Demand (COD)}

Chemical Oxygen Demand (COD) represents the amount of total oxygen required to oxidize either biodegradable or non-biodegradable organic matter chemically into $\mathrm{CO}_{2}$ and $\mathrm{H}_{2} \mathrm{O}$ [Alaert and Santika, 1984]. Furthermore, it shows the amount of oxygen required to oxidize organic and inorganic matter in a solution and, therefore, represents pollution by organic matter. Bacteria feed on decomposed organic matter. The energy used to decompose is resulted from oxidation.

COD is a measure of water pollution by naturally oxidized matter in microbiological process, which results in a reduction of dissolved oxygen in the water. Laboratory analysis shows that COD in Jonge Telaga varies between 3.51-6.77 $\mathrm{mg} / \mathrm{L}$ (Figure 5). It is below the accepted threshold for COD in a Class II water, as issued by the Governor Regulation of the Special Region of Yogyakarta Number 20 Year 2008, which is 25 $\mathrm{mg} / \mathrm{L}$. Therefore, Jonge Telaga is not experiencing a pollution by naturally oxidized matter resulted in microbiological processes.

\section{Detergent}

Detergent is a cleaning agent, such as soap, composed of petrochemical compounds. According to Alaert and Santika [1984], it has more advantage than soap because it positively reacts with hard water. Material used commonly in detergent is dodecylbenzenesulfonate. In hard waters, detergent ionizes forming an active bipolar component that binds $\mathrm{Ca}^{2+}$ or $\mathrm{Mg}^{2+}$. An intensive use of detergent along with its high content of phosphate is known to cause eutrophication. Detergent foam is destructive and deadly for biota presents in waters and/or their surrounding area because it prevents sunlight from providing oxygen for them. Therefore, abundant presence of detergent in a water degrades its quality.

All water samples show that the detergent level in Jonge Telaga varies between less than $0.0001 \mathrm{mg} / \mathrm{L}$ to $0.1672 \mathrm{mg} / \mathrm{L}$ (the lowest detection of the analysis equipment $=0.0001 \mathrm{mg} / \mathrm{L}$ ). Based on the Governor Regulation of the Special Region of Yogyakarta Number 20 Year 2008, detergent level in a Class II water is $200 \mu \mathrm{g} / \mathrm{L}$ or $0.02 \mathrm{mg} / \mathrm{L}$. Aside from sample B2 and C1, the water samples exceed the accepted threshold (Fig. 5), indicating a contamination by detergent. Field observation shows that its main source is washing directly in the doline pond.

\section{Biological Water Quality}

The analyzed biological water quality in the research is coli bacteria. They are a group of microorganisms with a length of $0.2-10 \mu \mathrm{m}$ and widespread in nature. Among of them is a group of coliform that represent water hygiene. E. coli is one of the harmless total coliform bacteria found in human feces. Abundant presence of E. coli in waters indicates contamination by human feces with probable concomitant pathogenic bacteria [Effendi, 2003]. Fecal coliform, part of total coliform, is $97 \%$ of coliform bacteria found in human feces. These bacteria are also found in animal feces. Based on the Governor Regulation of the Special Region of Yogyakarta Number 20 Year 2008, the accepted presence of coliform in a Class II water is 5,000 MPN/100 ml. Laboratory analysis shows that the total coliform of most of the water samples varies between 6-221 MPN/100 ml, which is below the accepted threshold for a Class II water. The variation of coliform presence in Jonge Telaga is presented in Figure. 6.

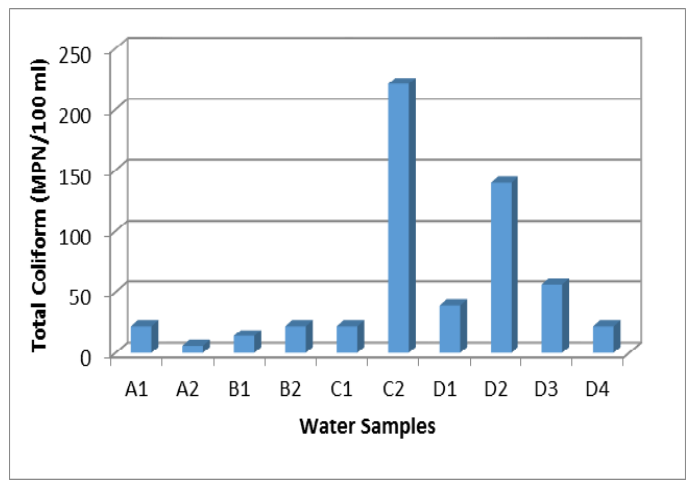

Figure 6. Total Coliform in Jonge Telaga

Based on the result of previous description showed that the main source of lake water quality degradation was waste domestic activities (washing and bathing) as well as raw waste from the tourist i.e. junk food wrappers and bottle that threw directly into the doline pond. It was proof by the increasing concentration of detergent and temperature value. It showed that the water bodies (lakes) quality was influenced by the environmental factors and activities in its surrounding. Land use is 
a representative of human activities and generate waste. The waste is a potential source of water pollution. According to Lundgren (1986), Domenico and Schwartz (1990), Sudarmadji (1991), and Fetter (1994), among others, is derived from domestic sewage (septic tank and latrines), industrial waste, mining waste, garbage, agricultural wastes. Cao, et al. (2016) explained that the impact of tourism activities affected the abundance of macroinvertebrates. The detrended correspondence analysis showed that water temperature and tourism index was strongly associated with the change of the assemblages composition. The composite samples i.e. benthic and light trap, were well fit with Poisson generalized model (adjusted R2 $=0.83$ and 0.85, respectively). It generally decreasing with increasing elevation, tourism index and total-N.

Similarly, the polluted environment was as pollutant sources of the lake besides the rock minerals from the surrounding geological conditions. The lake system in Croatia was as an example. Dautović, et al. (2014) explained that a complex karst lake system in the central Croatia was in situated polluted area. The main sources of several trace elements including toxic metals were $\mathrm{CD}, \mathrm{Zn}, \mathrm{Ni}$, and $\mathrm{Tl}$ lead to the Plitvice Lake system. The spatial trend of the most trace metal concentration (Mn, Fe, Al. Cd, Zn, Cu, Ni, Pb, Co, $\mathrm{Cr}, \mathrm{Tl})$ showed decreasing toward downstream from source to the lake. It due to of co-precipitation with authigenic calcite and Mn oxides to remove the dissolved elements in the lentic parts of system. William, et al. (2014) stressed that sources of streamflow and nutrient concentration are fundamental for the pollutant loadings assessment. Finally that can lead to the water quality impairments.

Another research was conduted by Gilboa, et al. (2015) made the scenario of landuse change on flow and pollutant loads discharge from watershed into the Lake Kinneret (Israel) using AVGWLF (ArcView (GIS) Generalized Watershed Loading Function) model. The Hydrological Model for Karst Environment (HYMKE) was another tool to support the AVGWLF to predict the daily flow stream. Improving the sediment transport and nutrient loads simulations used the Meditteranean Multiplication Factor (MMF). The result showed those model simulated the observe data with $\mathrm{R}^{2}>$ 0.70 and Nash-Sutcliffe efficiency more than 0.69 for flow rate, sediment and nutrient.

\section{Conclusion}

As a conclusion to the research results, the characteristics of Jonge Telaga represent a closed doline pond with continuous water availability throughout the year. Its main pollutant source is domestic activities (washing and bathing). Based on the Class II water quality standard issued in the Governor Regulation of the Special Region of Yogyakarta Number 20 Year 2008, Jonge Telaga meets all of the water quality criteria, except for the temperature and detergent.

In order to preserve as well as to sustain the function of Jonge Telaga, the research proposes a proper management for potentially pollutantproduced activities that will provide either direct or indirect impacts to the doline pond. For example, preventing direct access to the doline pond by providing a separated infrastructure close to it in order to accommodate washing and bathing activities. Aesthetically, solid waste (e.g. trash and organic waste) is very disturbing. Therefore, cleaning activities have to be improved in order to support Jonge Telaga as a local tourism object.

\section{Acknowledgments}

The research is conducted by the support of the Non-Tax Revenue in 2013 of the Faculty of Geography, Universitas Gadjah Mada. The author would like to express her sincere gratitude to the Dean of the Faculty of Geography, Universitas Gadjah Mada for providing the research grant. The author also would like to thank all of the research assistants: Erik Febriarta, S.Si., R. Syamsudin, Bayu Budi Prasetya, Mohamad Haviz D.S., Roza Oktama, Muhammad Abdul Aziz R., Danardono, Eko Bayu Dharma Putra, Ahmad Cahyadi, and Septian Fienastra, S.Si., M.T., as well as those who have helped the implementation of the research.

\section{References}

Alaerts \& Santika, S.S. (1984). Metoda Penelitan Air. Penerbit Usaha Nasional, Surabaya.(In bahasa Indonesia).

BLH (2008). Peraturan Gubernur Daerah Istimewa Yogyakarta Nomor 20 Tahun 2008 tentang Baku Mutu Air di Provinsi DIY. BLH Propinsi DIY, Yogyakarta. (In bahasa Indonesia).

BPS. (2012). Kecamatan Semanu Dalam Angka. BPS Kabupaten Gunungkidul, Yogyakarta. .(In bahasa Indonesia).

Cao,Y., Wang, B., Zhang, J., Wang, L., Pan, Y., Wang, Q., Jian. D., Deng, G. (2016). Lake Macroivertebrata Assemblages and Relationship with Natural Environment and Tourism Stress in Jiuzhaigou Natural Reserve, China. Ecological Indicator, vol. 2. pp. 182-190. 
Dautović, J., Fiket, Ž., Barešić, J. Ahel, M., Mikac, N. (2014). Source Distribution and Behaviour of Major and Trace Elements in a Complex Karst Lake System. Aquatic Geochemistry, vol. 20, pp. 19-38.

Domenico, P.A. \& Schwartz, F.W. (1990). Physical and Chemical Hydrogeology. John Wiley and Sons, New York.

Effendi, H. (2003). Telaah Kualitas Air. Kanisius, Yogyakarta. .(In bahasa Indonesia).

Fetter, C.W. (1994). Applied Hydrogeology. $3^{\text {rd }}$ Edition. Prentice Hall Inc, Englewood Cliffs, New Jersey.

Ford, D. \& Williams, D.W. (2007). Karst Geomorphology and Hydrology. John Wiley and Sons, London.

Gilboa, Y., Gal, G., Markel, D., Rimmer, A., Evans, B.M., and Friedler, E. (2015). Effect of Landuse Change scenarios on Nutriens and TSS Loads. Environmental Processes, vol 2(1), pp. 593-607.

Haryono, E. \& Adji, T.N. (2004). Pengantar Geomorfologi dan Hidrologi Karst. Kelompok Studi Karst, Fakultas Geografi, UGM.(In bahasa Indonesia)

Haryono, E., Adji, T.N., \& Widyastuti, M. (2009). Environmental Problems of Telaga (Doline Pond) in Gunung Sewu Karst, Java Indonesia. Proceedings, Vol. 2, Symposia Part 2. 15 the International Congress of Spelology. Texas.

Lundgren, L. (1986). Environmental Geology. Prentice-Hall, Englewood Cliffs, New Jersey.

Pannekoek, A.J., (1949). Outline of the Geomorphology Java. E.J. Brill, Luden.

Sudarmadji, Widyastuti, M., \& Haryono, E. (2005). Pengembangan Metode Konservasi Air Bawah Tanah di Kawasan Karst Sistem Bribin-Baron Kabupaten Gunungkidul. Laporan Penelitian Hibah Bersaing XIII/1. Lembaga Penelitian, UGM, Yogyakarta.(In bahasa Indonesia)

Sudarmadji, Widyastuti, M., \& Haryono, E. (2006). Pengembangan Metode Konservasi Air Bawah Tanah di Kawasan Karst Sistem Bribin-Baron Kabupaten Gunungkidul. Laporan Penelitian Hibah Bersaing XIII/2. Lembaga Penelitian, UGM, Yogyakarta.(In Bahas Indonesia)
Sudarmadji, Suprayogi, S., \& Setiadi. (2010). Konservasi Mataair berbasis Masyarakat di Kabupaten Gunungkidul untuk Mengantisipasi Dampak Perubahan Iklim. Laporan Penelitian Hibah Bersaing. Sekolah Pascasarjana, UGM, Yogyakarta.(In Bahasa Indonesia)

Surono, Toha, B., \& Sudarno, I. (1992). Peta Geologi Lembar Surakarta-Giritontro, Jawa Tengah. Pusat Penelitian dan Pengembangan Geologi (P3G) Departemen Pertambangan dan Energi, Bandung.(In bahasa Indonesia)

Sweeting, M.M. (1972). Karst of Britain, In Herak, M., and Stringfield, V.T. (ed), Karst: Important Karst Regions of the Northern Hemisphere. Elsevier Publishing Company, Amsterdam. (In Bahasa Indonesia

Tebbut, T.Y.H. (1992). Principle of Water Quality Control. $4^{\text {th }}$ Edition. Pergamon Press, Oxford.

White, W.B. (1988). Geomorphology and Hydrology of Karst Terrain. Oxford University Press, Oxford.

Widyastuti, M., Haryono, E., Sasongko, M.H.D., \& Prasetyo, B.B. (2014). Kajian Karakteristik Telaga Jonge (Doline Ponds) dari Aspek Morfologi dan Muatan Suspensi : Studi di Telaga Jonge Kecamatan Semanu, Kabupaten Gunungkidul dalam Seri Bunga Rampai Ekologi Lingkungan Kawasan Kars Indonesia-Menjaga Asa kelestarian Kawasan Karst Indonesia. Edisi 2. Deepublish, Yogyakarta. .(In bahasa Indonesia).

William, T.M., Amatya, D.M., Hitchcock, D.R., Edwards, A.E. (2014). Strealflow and Nutrient from a Karst Watershed with a Downstream Embayment : Chapel Branch Creek. Journal of Hydrologic Engineering, vol 19 (2), pp. 428-438. 